\title{
An osteometric approach to reconstruct the length and weight of Lutjanus argentiventris (Perciformes: Lujtanidae) for archaeological and ecological purposes
}

Correspondence:

María Fernanda Martínez-Polanco mfmartinezp@gmail.com

Submitted September 07, 2019

Accepted June 10, 2020

by Fernando Gibran

Epub September 04, 2020

Online version ISSN 1982-0224

Print version ISSN 1679-6225

Neotrop. Ichthyol.

vol. 18, no. 3, Maringá 2020

\section{${ }^{\oplus}$ María Fernanda Martínez-Polanco ${ }^{1,2}$ and ${ }^{\oplus}$ Philippe Béarez ${ }^{3}$}

Lutjanus argentiventris presents a large intertropical distribution within the Eastern Pacific, which is as important to fisheries now as it was in the pre-Hispanic period. The purpose of this article is to present an allometric model that enables the size and weight of $L$. argentiventris to be predicted, using the isolated bones found in archaeological and paleontological contexts or the stomach contents of ichthyophagous species. A modern collection of L. argentiventris from Ecuador was used, composed of 37 individuals covering a wide range of sizes and weights. The total length (TL), standard length (SL), and total fresh weight (W) of each individual was gathered. The TL of the sample ranged between 210 and $760 \mathrm{~mm}$, the SL between 164 and $627 \mathrm{~mm}$ and the W ranged between 123 and $6550 \mathrm{~g}$. The most frequent bones (15) and otoliths were chosen and 39 measurements were taken. The total length-weight relationship was $\mathrm{W}=6 \mathrm{E}-06 \mathrm{TL}^{3.1513}$ with $R^{2}=0.997$. In general, it was observed that the relationships between the TL and the bone measurements had a strong correlation $\left(R^{2}>0.95\right)$. The allometric model will be useful not only for archaeologists but also for biologists working on historical ecology.

Keywords: Allometry, Ichthyoarchaeology, Osteometry, Tropical Eastern Pacific, Length-weight relationship.
1 Àrea de Prehistòria, Universitat Rovira i Virgili (URV), Avinguda de Catalunya 35, 43002 Tarragona, Spain.

2 Institut Català de Paleoecologia Humana i Evolució Social (IPHES), C. Marcel.lí Domingo s/n, Campus Sescelades URV (EdificiW3), 43007 Tarragona, Spain. mfmartinezp@gmail.com (corresponding author).

3 Archéozoologie, archéobotanique: sociétés, pratiques et environnements (AASPE), Muséum national d'histoire naturelle, CNRS. CP 56, 57 rue Cuvier, 75005 Paris, France. bearez@mnhn.fr. 
Lutjanus argentiventris presenta una distribución intertropical en el Pacífico Oriental, siendo una especie importante desde épocas prehispánicas hasta la actualidad. El propósito de este artículo es presentar un modelo alométrico que prediga la talla y el peso de L. argentiventris, usando restos óseos aislados encontrados en contextos arqueológicos y paleontológicos. Se empleó una colección de 37 individuos con tallas y pesos variados, provenientes del Ecuador. La longitud total (LT), la longitud estándar (LE) y el peso (P) de cada individuo fueron recolectados. La LT varió entre 210 y $760 \mathrm{~mm}$, la LE entre 164 y $627 \mathrm{~mm}$ y el P entre 123 y $6550 \mathrm{~g}$. Se escogieron los huesos más frecuentes (15) y los otolitos para realizar 39 mediciones. La relación de la longitud total y el peso fue $\mathrm{P}=6 \mathrm{E}-06 \mathrm{TL}^{3,1513}$ con un valor de $R^{2}=0,997$. En términos generales se observa que las relaciones entre la LT y las medidas de los huesos presentan una correlación fuerte $\left(R^{2}>0,95\right)$. El modelo alométrico presentado puede utilizarse para predecir el tamaño y el peso, no sólo de L. argentiventris, sino también de sus congéneres, y será útil para arqueólogos y biólogos interesados en ecología histórica.

Palabras clave: Alometría, Ictioarqueología, Osteometría, Pacífico Oriental Tropical, Relación longitud-peso.

\section{INTRODUCTION}

The Lutjanidae family consists of 17 genera and 112 species, which are distributed in tropical and subtropical seas worldwide, but mostly in the Indo-Pacific (Fricke et al., 2020). The genus Lutjanus Bloch, 1790 is by far the most speciose, containing 73 species, including nine in the Eastern Pacific: Lutjanus aratus (Günther, 1864); L. argentiventris (Peters, 1869); L. colorado Jordan, Gilbert, 1882; L. guttatus (Steindachner, 1869); L. inermis (Peters, 1869), L. jordani (Gilbert, 1898); L. novemfasciatus Gill, 1862; L. peru Nichols, Murphy, 1922; and L. viridis (Valenciennes, 1846). The maximum total length (TL) of these species ranges between $300 \mathrm{~mm}$ (L. viridis) and $1700 \mathrm{~mm}$ (L. novemfasciatus) (Allen, 1985, 1995).

Snappers are important resources to artisanal and commercial fisheries worldwide, with the biggest catches in the Western Central Pacific and Western Central Atlantic (Allen, 1985; Salas et al., 2011). In the Tropical Eastern Pacific (TEP), the catch is less, however L. argentiventris is an important species for small-scale fisheries (e.g. Alava et al., 2015). In Mexico, the annual landings of the artisanal fleet have oscillated between 0.5 and $1.5 \mathrm{t}$ (Espino-Barr et al., 2004). A long-term study (1983-1998) of artisanal marine fisheries in Colima, Mexico, shows that L. argentiventris is the seventh most abundant species in the region's catches (Espino-Barr et al., 2002). At Bahia de Navidad, Jalisco, Mexico, another study, covering 47 months (5 days per month in 1994-1995 / 1998-2000) reveals that ten species accounted for more than $60 \%$ of the total abundance and biomass, with $L$. argentiventris in eighth place (Rojo-Vázquez et al., 2008). In the southwestern Gulf of California, Mexico, L. argentiventris is among the eight most commercially important reef fishes (Erisman et al., 2010). It is normally captured using various types of craft nets, gillnets, harpoons, and hook-and-lines (Rojas et al., 2004; Lucano-Ramírez et al., 2014). 
The archaeological record shows the importance of the species along the Pacific coast for millennia. In Mexico, archaeo-ichthyological samples from the site of Huatabampo (Sonora) exhibit high numbers (Number of identified specimens [NISP] = 106; Minimum number of individuals $[\mathrm{MNI}]=10$ ) of snappers (Lutjanus cf. argentiventris). The presence of this species suggests that the ancient inhabitants of Huatabampo were fishing in areas with a strong marine influence (Guzmán, 2008). In Panama, snappers are present in the archaeological material of Cerro Mangote (Cooke, Ranere, 1999) and, more commonly, in the Pearl Islands archipelago, in Pedro Gonzalez (Cooke, Jiménez, 2009) and Bayoneta Island (Martínez-Polanco et al., 2009). Pre-Ceramic occupations at Pedro Gonzalez (4030-3630 BC) and Ceramic occupations at Bayoneta Island (ca. 900 and $1300 \mathrm{AD}$ ) fishing data suggest that snappers were taken with similar frequency during both time periods (Cooke, Jimenez-Acosta, 2009; Martínez-Polanco et al., 2009). Snappers are evenly distributed in low numbers in Ecuadorian sites (e.g. Béarez, 1996; Béarez et al., 2012).

Just as the weight increases with the size of the fish, bone size also increases with body size. The growth rate of each body part varies depending on species ontogeny and morphology (Teissier, 1948). In archaeology, fish body size and weight are used to study human diet, and to infer on fishing strategies and techniques, human exploitation and the overexploitation of fish faunas (e.g. Reitz et al., 1987; Lambrides, Weisler, 2015; Thieren, Van Neer, 2016; Prestes-Carneiro, Béarez, 2017; Lidour et al., 2018; Rurua et al., 2020). In particular, some aspects of fishing can be studied in depth: (1) changes in the geographic ranges of species, (2) reductions in their abundances, (3) signatures of trophic cascades and (4) marine fisheries trophic level changes (Erlandson, Rick, 2010).

On the other hand, Karachle, Stergiou (2012) summarize the importance of lengthweight models in three aspects of modern ecology studies: (1) use of length data as an estimation of biomass; (2) to ascertain the condition of the species; and (3) to compare the life history of different populations of the same species. In fisheries management, the weight and the size of fish are used to estimate population parameters, life history characteristics and to develop programs for the protection and management of the species (Castellanos-Galindo, Zapata-Padilla, 2019). This kind of information could be used to determine the minimum permissible lengths of capture and identification of suitable periods for a closed fishing season. The identification of age-classes and male to female ratios are relevant to evaluate the status of an exploited stock and to establish future harvest levels, and the relationship between fish-size and its life-history traits and habitats (Castellanos-Galindo, Zapata-Padilla, 2019; Froese, Pauly, 2019).

In modern fisheries, the concept of baseline is understood as the fish population that was present before human influence (Pauly, 1995). This author addresses the shifting baseline syndrome, but this can only be resolved by developing a pre-industrial baseline that extends beyond the origins of modern fishing, both artisanal and commercial (Froyd, Willis, 2008; Betts et al., 2011, 2014; Barrett, 2019). Baselines should not assume static environments but rather dynamic systems (Rick, Lockwood, 2012). It is in this point where zooarchaeology and particularly ichthyoarchaeology can contribute with information to manage modern fisheries (Betts et al., 2011, 2014; Barrett, 2019). Fish size comparison between modern, historical and archaeological data could be used to regulate marine protected areas and to propose clear conservation objectives. For example, if archaeological data are used as baselines, new indicators could be proposed, 
and compared over time. Similarly, reference levels of objectives, thresholds or limits could be developed to inform the management of marine resources and ecosystems (Schwerdtner-Máñez et al., 2014). At the same time, it could determine the absolute magnitude of the changes that can occur in a heavily exploited fish stock. Analysis of long-term trends in fish size can provide a key indicator of changes in ecological baselines (Betts et al., 2011, 2014; Barrett, 2019). Other contributions of the study of the archaeological fish size are to measure fluctuations in the aquatic environment and the intensity of exploitation (Betts et al., 2011, 2014; Barrett, 2019).

In this article, the attention will focus on the yellow snapper, L. argentiventris, which has a subtropical distribution, ranging in the Eastern Pacific from southern California to northern Peru, including the Galapagos Islands (Allen, 1985) (Fig. 1). The species is found in coral and rocky reefs at a depth range of 3-60 m and also in estuaries and river mouths, being tolerant to freshwater. It is characterized by a pinkish red colour of the anterior part of the body, which becomes bright orange to yellow in its posterior part. The fins are mainly yellow or orange. The yellow snapper is an active predator, feeding mainly at night on fish, shrimp, crabs and mollusks (Allen, 1985). Individuals can form small aggregations during the day or shelter in caves. The species also form seasonal spawning aggregations, a trait that makes many species vulnerable to overfishing (Sala et al., 2003). The species has been recorded up to a TL of $760 \mathrm{~mm}$ and a maximum weight (W) of $6550 \mathrm{~g}$ (Béarez, 1996: 44). For Gorgona Island in Colombia, Rojas et al. (2004) reported that the average size at sexual maturity was $515 \mathrm{~mm}$ TL and that the length-weight relationships were not significantly different between sexes. In the case of the central Mexican Pacific, the size range at sexual maturity was $260-330 \mathrm{~mm}$ for females and 240-320 mm for males (Lucano-Ramírez et al., 2014).

Our purpose is to present an allometric model that enables the length and weight of Lutjanus argentiventris to be predicted, using the isolated bones from archaeological and paleontological contexts or the stomach contents of ichthyophagous species. Lengthweight relationships for L. argentiventris can be found for Mexico (González et al., 2004; Aburto-Oropeza et al., 2009; García-Contreras et al., 2009; Piñón et al., 2009; VelázquezVelázquez et al., 2009), Panama (Bonilla-Gómez et al., 2014) and Colombia (Rojas et al., 2004) but not for Ecuador. As there is no information available for the southernmost part of the range of $L$. argentiventris, it is useful to check whether this relationship is similar or different from those already known in more northern countries. Rojas et al. (2004) reported that the species is moderately slow growing, appears to be long-lived and has a low natural mortality rate, making it easily vulnerable to overfishing. It is therefore important to build osteometric models that could be used for in-depth long-term studies of $L$. argentiventris populations, with the aim of proposing management strategies.

\section{MATERIAL AND METHODS}

All the skeletons came from the fish collection of the Muséum national d'histoire naturelle in Paris. The modern collection of Lutjanus argentiventris is composed of 37 individuals covering a wide range of sizes and weights: 36 are from Ecuador and one is from Panama. The TL of the sample ranged between 210 and $760 \mathrm{~mm}$, and the SL between 164 and $627 \mathrm{~mm}$. The W ranged between 123 and $6550 \mathrm{~g}$. The fish from 


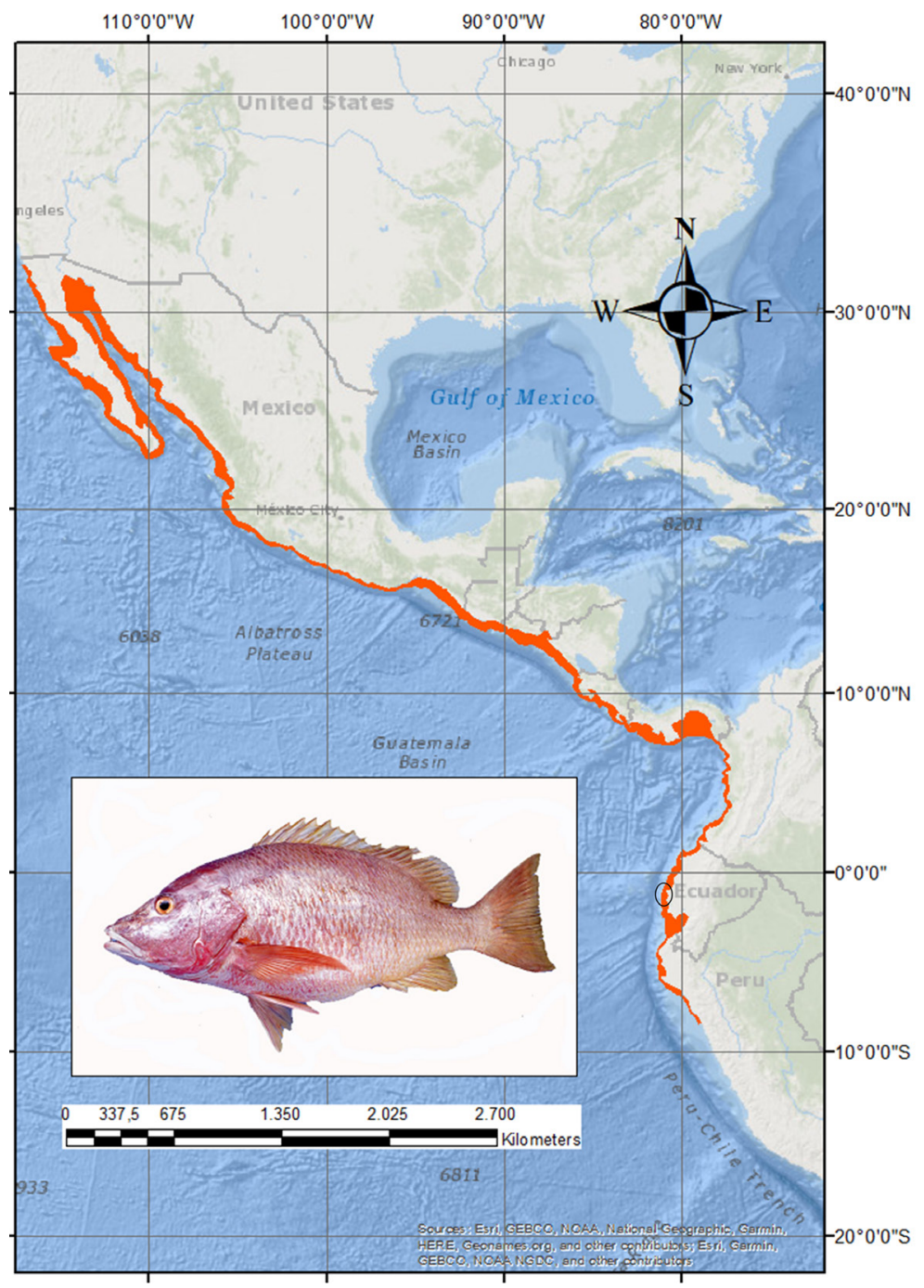

FIGURE 1 I Lutjanus argentiventris geographical distribution (Map adapted from Robertson, Allen, 2015; Image represents a $645 \mathrm{~mm}$ TL individual).

Ecuador (MNHN-ICOS-1776 to -1811) were sampled between 1992 and 1998 in the vicinity of Puerto López (Fig. 1) mostly over rocky reefs, and using harpoons. The specimen from Panama (MNHN-ICOS-1812) was sampled at Isla del Rey (Pearl Island Archipelago) in 2000. All individuals have complete information about their total length (TL) and standard length (SL), which were recorded in millimeters ( $\mathrm{mm})$, and their total fresh weight (W) in grams (g).

Specimens from other Lutjanus species were also used, such as: L. novemfasciatus (n = 3); L. colorado $(\mathrm{n}=1)$; L. peru $(\mathrm{n}=1) ;$ L. guttatus $(\mathrm{n}=4)$ and L. argentimaculatus $(\mathrm{n}=$ 1). These specimens were also collected from the same locations and at the same time period as L. argentiventris, except for the last one which comes from Kenya (Indian Ocean). For this study, all the specimens were used, including the Panamanian specimen and the other species individuals, to test the model. We included other species because in the archaeological record it is sometimes very difficult to arrive at a species level 
determination, at times we only succeed to determine the genus, which is quite often the case within the genus Lutjanus (e.g. Guzmán, 2008).

Among the most frequently preserved bones in the archaeological archives, 15 were selected, 39 measurements were taken, and otoliths were included (Tab. 1, Fig. 2). Measuring points were chosen in such a way that they had a good probability of being found among archaeological remains; for this reason, the slender and fragile parts were discarded and the robust parts were preferred (Desse, 1984). The measurements were taken using a digital caliper with a precision of two decimal points. Following convention, the left side bones were measured. However, in the case of the otoliths, both sagittae (left and right) were measured and a two-sample (paired samples) t-test was performed in order to identify eventual differences between sides (the null hypothesis being that the means of two populations are equal).

An allometric regression model was employed to determine the length-length and length-weight relationships for the L argentiventris collection. This model assumes that the growth of each body part is relative to its total body length and weight, but with distinct growth rates (Teissier, 1948; Reitz et al., 1987; Marean et al., 2001). The lengthweight relationship is represented by a power function:

$$
\mathrm{Y}=\mathrm{aX}
$$

Where "Y" is the total weight of the fish, " $\mathrm{X}$ " is the total length, "a" a constant and "b" the allometric coefficient. To create this model, we also used 11 more specimen data (TL, SL, W) measured in Ecuador from fresh fishes that could not be preserved. The total sample was 48 (37 collected and preserved fishes +11 fresh fishes not preserved).

In the case of the length-length relationships the same function was used; however, "Y" is the total length, and " $\mathrm{X}$ " is the body part measurement. The quality of the relationship is given by the coefficient of determination $\left(R^{2}\right)$. The best fitted measurements allowed us to reliably estimate the length and the weight of the fish from its isolated bones.

Desse et al. (1989) proposed to establish Global Rachidian Profiles (GRP) to identify the position of the vertebrae along the spine. This approach is really helpful in archaeological cases where the vertebrae are the most common element. At the same time, by knowing the height of an archaeological vertebra it is possible to estimate the size of an individual. To construct the GRP of $L$. argentiventris, four individuals with different sizes were selected, and measurements were taken on the caudal (diameters M1 and M2) and ventral faces (M3) of the vertebrae (Tab. 1, Fig. 2).

\section{RESULTS}

The total length-weight relationships reflected a slight allometric growth $(b=3.1513)$, with a high coefficient of determination $\left(R^{2}=0.997\right)$ (Tab. 2, Fig. 3).

In general, it was observed that the relationships had a strong correlation $\left(R^{2}>0.95\right)$ (see Tab. 1, Fig. 2 for bone measurements). The measurements relating to the maximal length of the element were well correlated with the TL. However, other measurements, based on small parts of the bones, which are the most frequently preserved, were also well correlated (see Fig. 4 for other Lutjanus species and the Panamanian specimen). 
TABLE 1 I Lutjanus argentiventris bone measurements descriptions (see also Fig. 2).

\section{Measurement Abbrev.}

Vomer M1 Vo M1

Basioccipital M1 Boc M1

Basioccipital M2 Boc M2

Premaxilla M1

Premaxilla M2

Premaxilla M3

Dentary M1

Dentary M2

Dentary M3

Maxilla M1

Maxilla M2

Maxilla M3

Anguloarticular M1

Anguloarticular M2

Anguloarticular M3

Quadrate M1

Quadrate M2

Quadrate M3

Palatine M1

Palatine M2

Palatine M3

Hyomandibula M1

Hyomandibula M2

Hyomandibula M3

Preopercle M1

Preopercle M2

Preopercle M3

Opercle M1

Opercle M2

Opercle M3

Post-temporal M1

Post-temporal M2

Supracleithrum M1

Supracleithrum M2

Cleithrum M1

Cleithrum M2

Cleithrum M3

Otolith sagitta M1

Otolith sagitta M2
Pmx M1

Pmx M2

Pmx M3

Dn M1

Dn M2

Dn M3

Mx M1

Mx M2

Mx M3

Ang M1

Ang M2

Ang M3

Qd M1

Qd M2

Qd M3

Pal M1

Pal M2

Pal M3

Hm M1

Hm M2

Hm M3

Pop M1

Pop M2

Pop M3

Op M1

Op M2

Op M3

Ptp M1

Ptp M2

Spcl M1

Spcl M2

Cl M1

Cl M2

Cl M3

Oto M1

Oto M2
Description

Maximal mediolateral width of the vomer

Maximal width of the articular surface of the basioccipital

Maximal height of the articular surface of the basioccipital

Maximal length of the premaxilla

Rostro-caudal length of the basis of combined ascending and articular processes

Thickness of the ascending process at mid-height distance from the lower part of the symphysis to the coronid fossa

Maximal length, from the rostral tip of the dentary to the caudal tips of the coronoid and ventral processes

Height of the symphysis

Maximal width of the rostral extremity

Maximal length of the maxilla, from the rostral tip of the external process to the tip of the caudal processes

Maximal width of the dorsal condyle

Medio-lateral width at posterior level of the dorsal process

Maximal length between the line joining the quadrate facet and the post-articular process and the rostral tip of the anterior process

Distance between the cranio-ventral tip and the little notch situated between the quadrate facet and the postarticular process

Maximal width of the quadrate facet

Distance between the tip of the mesial condyle and the tip of the preopercular process

Distance between the ventral tip of the mesial condyle and the dorsal tip of the ectopterygoid margin

Distance between the external tip of the lateral condyle and the internal tip of the mesial condyle

Maximal length of the palatine, Dorso-ventral diameter of the anterior (maxillary) process (M3)

Distance between the recess situated in the condyle coiling and the cranial tip of the maxilla process

Distance between the median recess of the dorsal edge and the posteroventral base of the anterior (maxillary) process (M2)

Distance between the symplectic facet and the line joining the tips of the sphenotic and pterotic facets

Distance between the sphenotic facet and the opercular process

Distance between the ventral bases of the pterotic facet and the opercular process

Maximal length of the preopercle

Distance between the anterior margin and the median notch of the posterior margin

Maximal thickness of the quadrate crest

Distance from the supra-articular process to the ventral extremity of the opercle

Height of the articular fossa

Cranio-caudal length of the articular fossa

Distance between the tip of the dorsal process and the articular facet

Distance between the tip of the ventral process and the articular facet

Maximal length of the supracleithrum

Maximal thickness of the supracleithrum in its median part

Maximal length of the cleithrum

Distance between the tip of the anterodorsal process and the scapula joint

Width of the cleithrum at level of the posterodorsal notch

Maximal length (rostro-caudal axis)

Maximal height (dorso-ventral axis)

Regarding the GRP, four M2 profiles from four individuals are represented in Fig. $5 \mathrm{~A}$, and profiles for the M1, M2 and M3 of a single individual are represented in Fig. 5B. In both figures, two main zones could be distinguished: the anterior zone from 


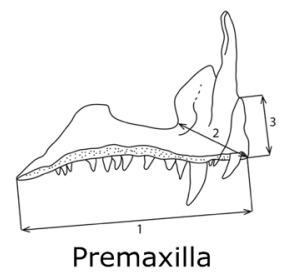

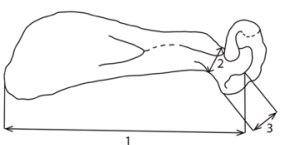

Maxilla
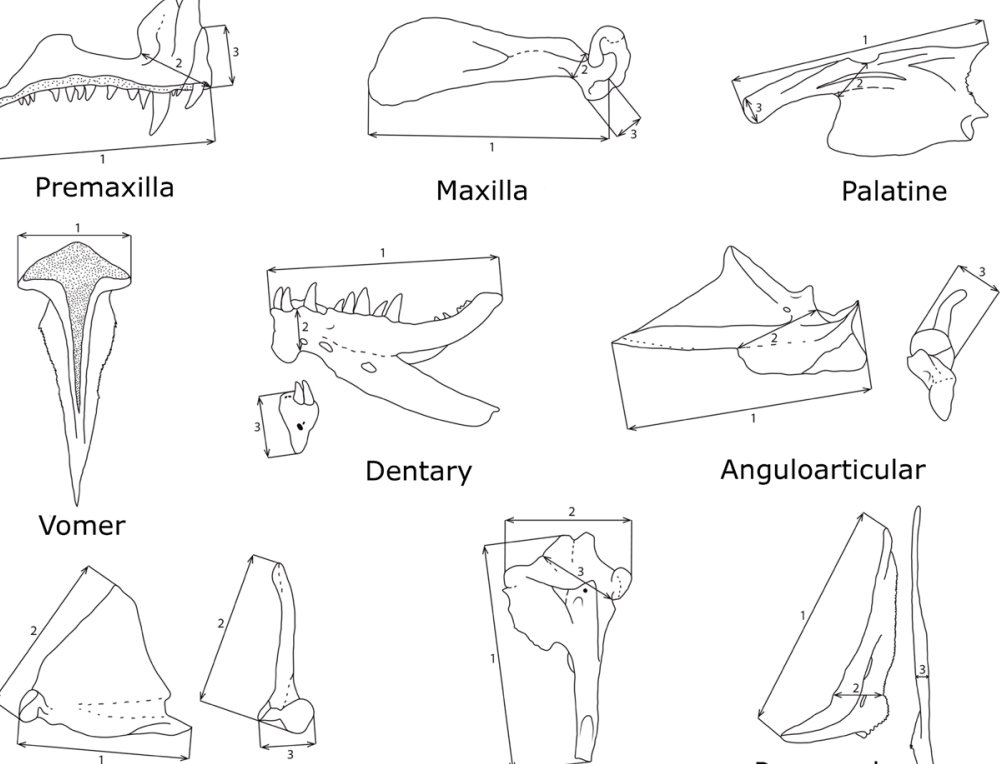

Quadrate

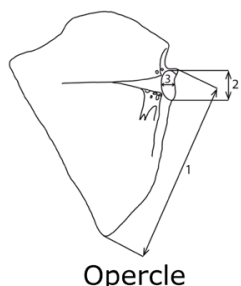

Opercle

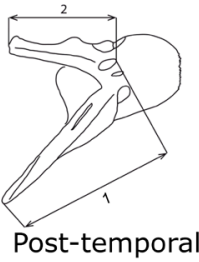

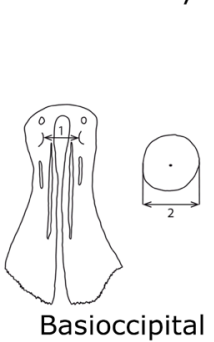

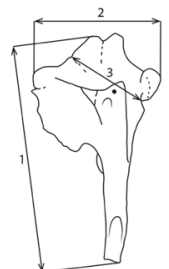

Hyomandibula

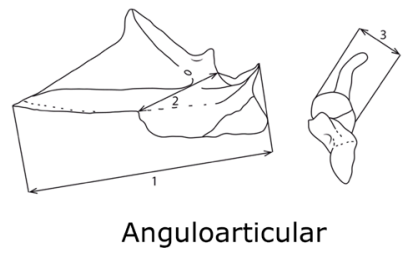

Anguloarticular
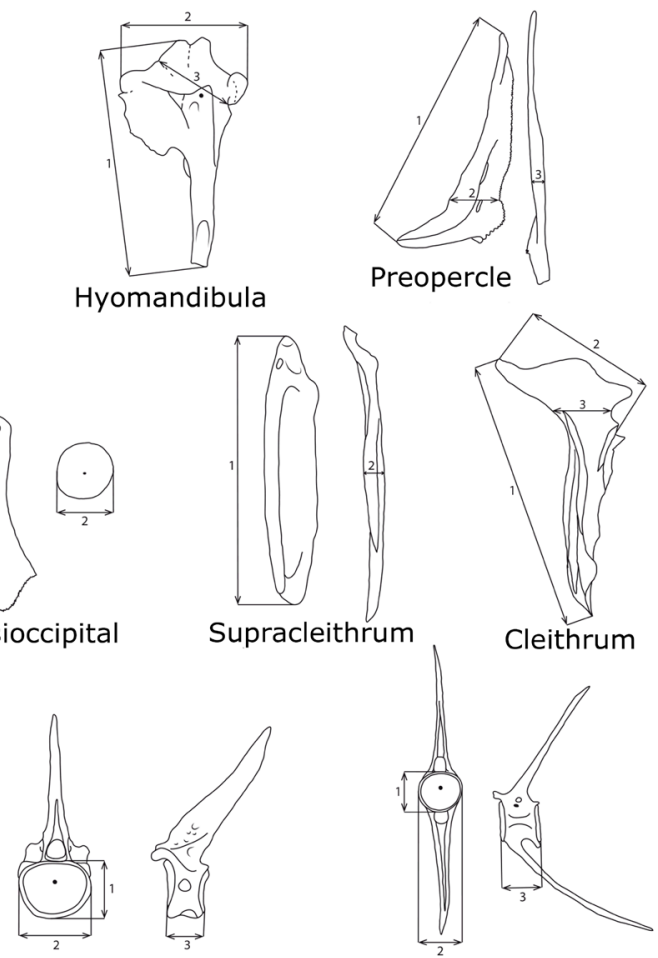

3rd Precaudal vertebra

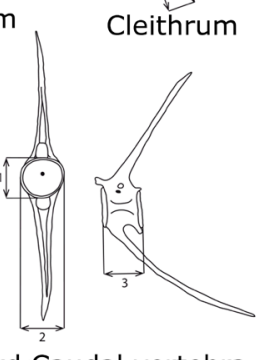

FIGURE 2 । Lutjanus argentiventris bone measurements.

vertebrae 1 to 7 , and the posterior zone from vertebrae 8 to 24 . The anterior zone is more heterogeneous while the posterior zone is more homogeneous.

In the case of the otoliths, it was observed that the exponent of the allometric equation was superior to 1 (Tab. 2). This implies that they grow more slowly than the rest of the body. There were no significant differences between the length, height and weight of the right and left otoliths (Tab. 3).

Some degree of similarity was observed between the "b" values of the length-weight relationship obtained in this study and those from previous studies from Mexico, Panama and Colombia (Tab. 4). These results indicate that Lutjanus argentiventris has a similar, often isometric, growth all along its range. 
TABLE 2 I Lutjanus argentiventris length to length and length to weight equation parameters (Length in $\mathrm{mm}$ and weight in $\mathrm{g})(\mathrm{n}=37)$.

\begin{tabular}{|c|c|c|c|c|c|c|c|c|c|c|c|}
\hline Body element & Measurement & $\mathbf{n}$ & Mean & SD & Min. & Max. & Relationship & $\mathbf{a}$ & $\mathbf{b}$ & $\mathbf{R}$ & r2 \\
\hline Standard length & & 48 & 362.27 & 133.58 & 164.00 & 627.00 & TL vs. SL & 0.84110 & 17.71600 & 0.998 & 0.999 \\
\hline Total length & & 48 & 451.75 & 160.01 & 210.00 & 760.00 & W vs. TL & 0.00001 & 3.15130 & 0.997 & 0.999 \\
\hline Weight & & 47 & 1902.43 & 1794.05 & 123.00 & 6550.00 & W vs. SL & 0.00003 & 3.00870 & 0.996 & 0.998 \\
\hline Vomer & 1 & 34 & 12.86 & 4.91 & 6.52 & 25.33 & vo M1 vs. TL & 36.46500 & 0.94810 & 0.980 & 0.990 \\
\hline \multirow{2}{*}{ Basioccipital } & 1 & 35 & 3.66 & 1.46 & 1.78 & 8.21 & boc M1 vs. TL & 127.57000 & 0.89530 & 0.906 & 0.952 \\
\hline & 2 & 35 & 7.17 & 3.46 & 3.37 & 16.73 & boc M2 vs. TL & 89.47600 & 0.77720 & 0.965 & 0.982 \\
\hline \multirow{3}{*}{ Premaxilla } & 1 & 36 & 30.77 & 12.27 & 15.84 & 61.97 & pm M1 vs. TL & 16.45600 & 0.93400 & 0.995 & 0.998 \\
\hline & 2 & 36 & 9.36 & 4.18 & 4.58 & 20.53 & pm M2 vs. TL & 60.46500 & 0.85200 & 0.981 & 0.991 \\
\hline & 3 & 36 & 7.10 & 3.61 & 2.78 & 17.71 & pm M3 vs. TL & 94.61600 & 0.74790 & 0.956 & 0.978 \\
\hline \multirow{3}{*}{ Dentary } & 1 & 36 & 32.23 & 12.01 & 16.80 & 63.02 & dn M1 vs. TL & 13.06600 & 0.98690 & 0.996 & 0.998 \\
\hline & 2 & 36 & 6.77 & 3.08 & 3.22 & 14.35 & dn M2 vs. TL & 85.51900 & 0.81810 & 0.986 & 0.993 \\
\hline & 3 & 36 & 19.41 & 7.03 & 10.40 & 33.19 & dn M3 vs. TL & 20.21900 & 1.00760 & 0.979 & 0.989 \\
\hline \multirow{3}{*}{ Maxilla } & 1 & 36 & 35.05 & 13.95 & 17.85 & 71.75 & mx M1 vs. TL & 14.30200 & 0.93920 & 0.996 & 0.998 \\
\hline & 2 & 36 & 5.22 & 2.46 & 2.23 & 11.69 & mx M2 vs. TL & 111.30000 & 0.78710 & 0.984 & 0.992 \\
\hline & 3 & 36 & 6.78 & 2.78 & 3.54 & 15.48 & mx M3 vs. TL & 68.77500 & 0.92470 & 0.968 & 0.984 \\
\hline \multirow{3}{*}{ Anguloarticular } & 1 & 35 & 36.35 & 13.11 & 18.80 & 66.73 & ar M1 vs. TL & 10.52800 & 1.01500 & 0.995 & 0.997 \\
\hline & 2 & 35 & 12.97 & 4.95 & 6.27 & 23.11 & ar M2 vs. TL & 35.52900 & 0.94980 & 0.985 & 0.992 \\
\hline & 3 & 35 & 5.97 & 2.99 & 2.68 & 15.26 & $\operatorname{ar} \mathrm{M} 3$ vs. TL & 101.64000 & 0.78360 & 0.984 & 0.992 \\
\hline \multirow{3}{*}{ Quadrate } & 1 & 36 & 24.05 & 8.77 & 12.53 & 45.31 & qd M1 vs. TL & 16.23600 & 1.00900 & 0.994 & 0.997 \\
\hline & 2 & 36 & 20.41 & 8.70 & 10.28 & 41.48 & qd M2 vs. TL & 28.70700 & 0.87800 & 0.988 & 0.994 \\
\hline & 3 & 36 & 6.63 & 2.94 & 3.32 & 14.36 & qd M3 vs. TL & 79.06500 & 0.86520 & 0.987 & 0.994 \\
\hline \multirow{3}{*}{ Palatine } & 1 & 36 & 26.87 & 10.26 & 13.89 & 52.15 & pl M1 vs. TL & 16.88700 & 0.96390 & 0.994 & 0.997 \\
\hline & 2 & 36 & 5.78 & 2.47 & 2.87 & 12.51 & pl M2 vs. TL & 86.18100 & 0.88170 & 0.963 & 0.981 \\
\hline & 3 & 36 & 1.59 & 0.81 & 0.75 & 3.62 & pl M3 vs. TL & 290.91000 & 0.74100 & 0.924 & 0.961 \\
\hline \multirow{3}{*}{ Hyomandibula } & 1 & 36 & 33.54 & 13.34 & 17.14 & 67.32 & hm M1 vs. TL & 14.95100 & 0.93840 & 0.993 & 0.996 \\
\hline & 2 & 36 & 18.10 & 7.35 & 8.96 & 36.47 & hm M2 vs. TL & 28.66100 & 0.91400 & 0.992 & 0.996 \\
\hline & 3 & 36 & 12.96 & 5.17 & 6.32 & 25.86 & hm M3 vs. TL & 41.47900 & 0.88100 & 0.949 & 0.974 \\
\hline \multirow{3}{*}{ Preopercle } & 1 & 36 & 57.29 & 22.37 & 29.12 & 112.08 & pop M1 vs TL & 8.85350 & 0.94350 & 0.997 & 0.998 \\
\hline & 2 & 36 & 12.55 & 5.27 & 6.70 & 24.74 & pop M2 vs. TL & 42.64300 & 0.88920 & 0.951 & 0.975 \\
\hline & 3 & 36 & 2.98 & 1.55 & 1.40 & 7.39 & pop M3 vs. TL & 183.24000 & 0.73870 & 0.941 & 0.970 \\
\hline \multirow{3}{*}{ Opercle } & 1 & 36 & 34.70 & 14.59 & 17.27 & 68.15 & op M1 vs. TL & 17.21400 & 0.89060 & 0.990 & 0.995 \\
\hline & 2 & 36 & 5.26 & 2.38 & 2.32 & 12.17 & op M2 vs. TL & 100.66000 & 0.84070 & 0.962 & 0.981 \\
\hline & 3 & 36 & 4.72 & 1.93 & 2.54 & 9.39 & op M3 vs. TL & 97.03600 & 0.91910 & 0.958 & 0.979 \\
\hline \multirow{2}{*}{ Post-temporal } & 1 & 36 & 21.31 & 8.26 & 11.16 & 40.22 & ptp M1 vs. TL & 21.78000 & 0.95400 & 0.989 & 0.994 \\
\hline & 2 & 36 & 14.13 & 4.85 & 6.71 & 23.75 & ptp M2 vs. TL & 28.24000 & 1.00140 & 0.968 & 0.984 \\
\hline \multirow{2}{*}{ Supracleithrum } & 1 & 35 & 31.09 & 11.75 & 15.99 & 57.79 & scl M1 vs. TL & 14.71700 & 0.96450 & 0.989 & 0.995 \\
\hline & 2 & 35 & 2.52 & 1.04 & 1.29 & 5.01 & scl M2 vs. TL & 177.00000 & 0.89950 & 0.964 & 0.982 \\
\hline \multirow{3}{*}{ Cleithrum } & 1 & 35 & 70.36 & 28.67 & 35.02 & 139.09 & cl M1 vs. TL & 8.42960 & 0.91150 & 0.996 & 0.998 \\
\hline & 2 & 35 & 34.80 & 14.07 & 16.82 & 68.10 & cl M2 vs. TL & 15.79000 & 0.91510 & 0.988 & 0.994 \\
\hline & 3 & 35 & 9.12 & 3.04 & 5.14 & 17.04 & cl M3 vs. TL & 37.12200 & 1.07600 & 0.892 & 0.944 \\
\hline \multirow{2}{*}{ Otolith sagitta } & 1 & 30 & 11.53 & 2.80 & 7.26 & 17.53 & oto M1 vs. TL & 12.52300 & 1.41320 & 0.963 & 0.981 \\
\hline & 2 & 30 & 6.59 & 1.87 & 3.85 & 11.08 & oto M2 vs. TL & 37.20100 & 1.25850 & 0.975 & 0.987 \\
\hline
\end{tabular}




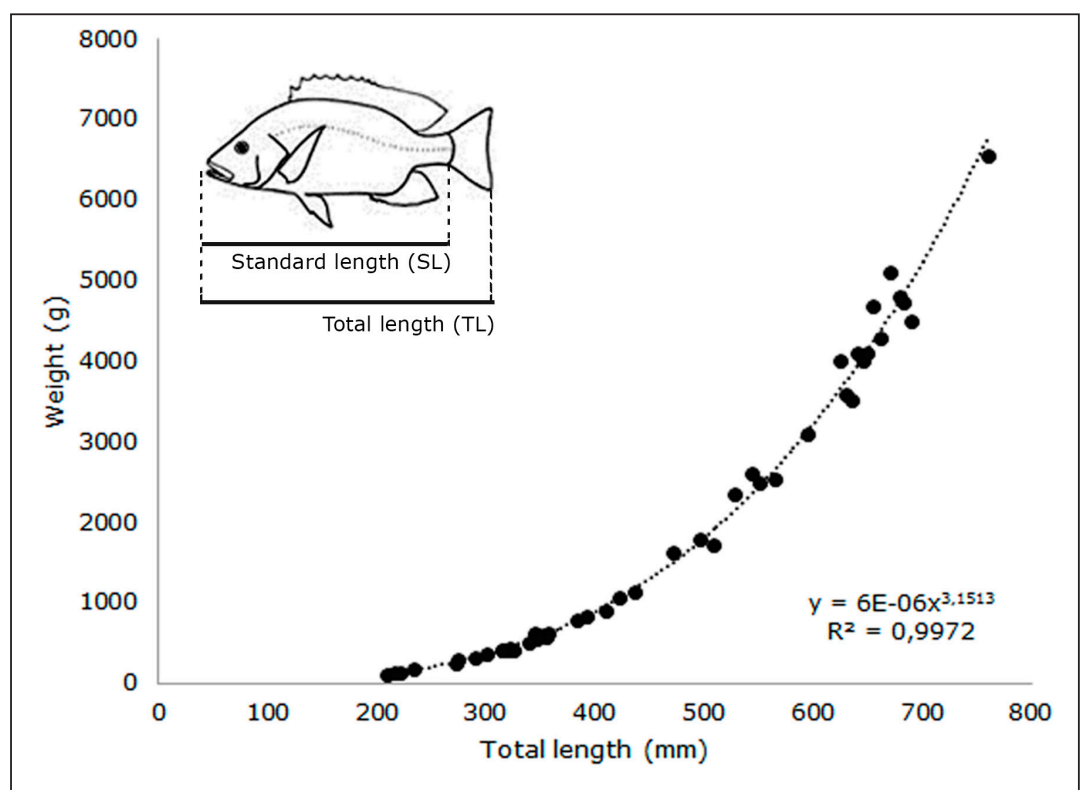

FIGURE 3 I Total length (TL) to weight relationship of the modern sample of Lutjanus argentiventris.

The tests made using other species of the same genera (Fig. 4) showed that the model could be used, at least in some instances, at genus level without much distortion. This is an important issue when dealing with Lutjanus species from other geographic areas. With regards the GRP profiles, the similar M2 values of the vertebrae of the posterior zone (Fig. 5) allowed us to use their measurement without knowing their exact rank in the rachis, which is often difficult to determine with isolated caudal vertebrae.

The otoliths on both sides can be used to estimate the size of the fish (Tab. 3).

\section{DISCUSSION}

The relationships between bone measurements and body-length were robust (Tab. 2), which makes us confident that they can be used with archaeological samples. Also, it is interesting to point out that the model also works with small fish, such as the $109 \mathrm{~mm}$ TL Panamanian specimen (Fig. 4). Such applications have already been carried out and have shown their interest. This is notably the case of recent studies in the fresh waters of South America (Peña-León, 2011, 2013; Prestes-Carneiro et al., 2019) or in the marine waters of the Persian Gulf (Yeomans, 2015; Lidour et al., 2018).

However, this kind of study is not frequent in Latin American archaeological literature of despite its great informative potential. The study of the body length of the archaeological L. argentiventris could provide information on where the specimens were captured, depending on their size, and on ancient fishing techniques. The early life stages of $L$. argentiventris are found in mangroves, estuaries or shallow bays, which provide them with food and protection from large predators; adults then move to the outer rocky reefs where they continue to grow (Rojas et al., 2004). With this in mind, small-sized archaeological fish are expected to have been captured in mangroves, or at least close inshore, while larger fish came from deeper waters. The proportion of 
A.

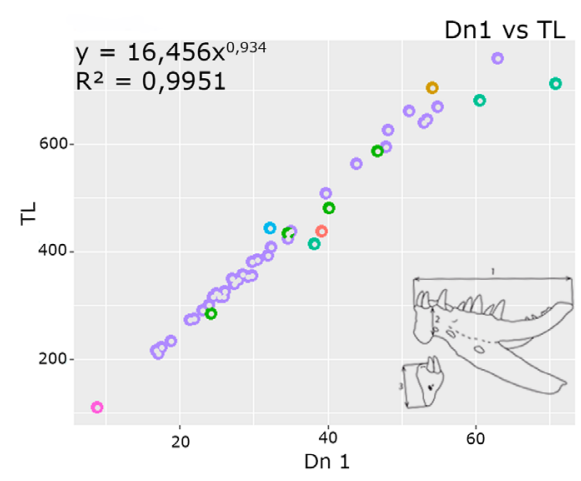

D.

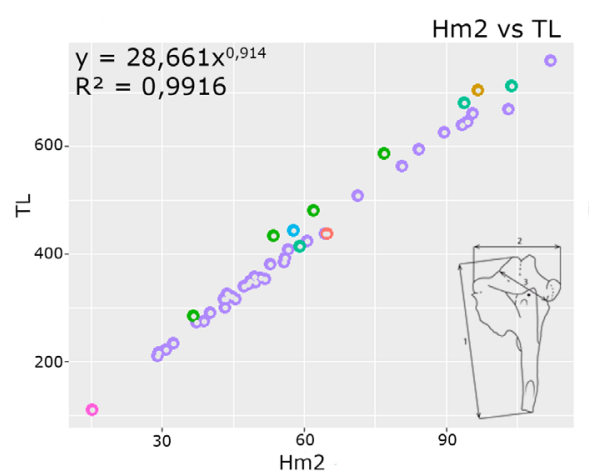

B.

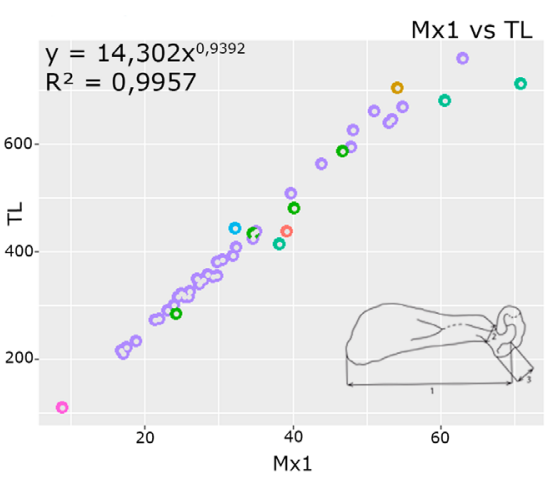

E.

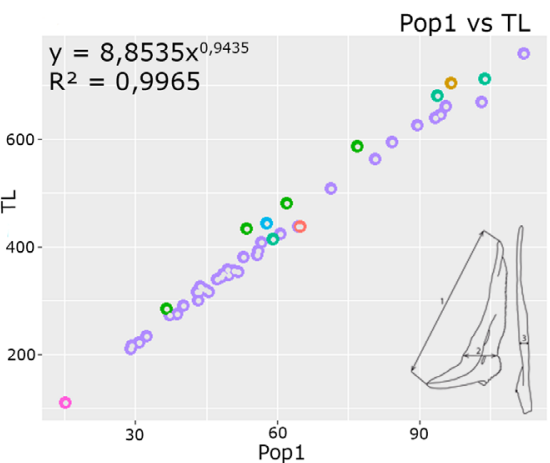

c.

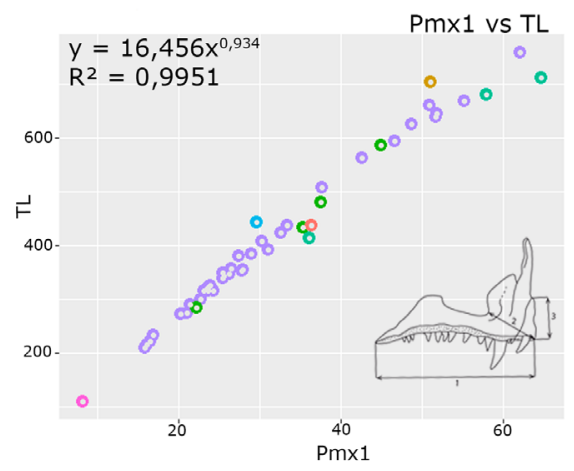

F.

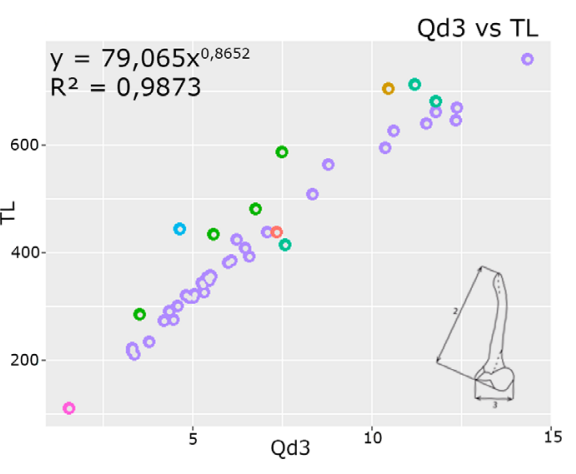

Figure legend

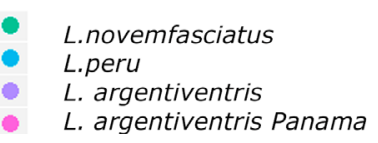

- L. argentimaculatus

- L. colorado

- L.guttatus

FIGURE 4 I Examples of Lutjanus argentiventris graphs modelling the regression formulae. A. Dentary (Dn1); B. Maxilla (M1); C. Premaxilla (Pmx1); D. Hyomandibula (Hm2); E. Preopercle (Pop1) and F. Quadrate (Qd3).

TABLE 3 I Lutjanus argentiventris otholith measurements.

\begin{tabular}{|c|c|c|c|c|c|}
\hline Measurement & Side & $\mathbf{n}$ & Mean & $\mathbf{t}$ & $\boldsymbol{p}$ \\
\hline \multirow{2}{*}{ Length } & right & 30 & 11.36 & -0.0352 & 0.9721 \\
\hline \multirow{2}{*}{ Height } & left & 30 & 11.36 & & \\
& right & 30 & 6.48 & & 0.6758 \\
\hline \multirow{2}{*}{ Weight } & left & 30 & 6.50 & -0.4224 & \\
\hline & right & 30 & 0.16 & & \\
\hline
\end{tabular}

juveniles to adults can also provide information about fishing grounds and/or the health of nurseries and, beyond that, mangroves. However, these inferences should be accepted with caution because different populations of the same species may present different life history characteristics (e.g. Rojas et al., 2004, Lucano-Ramírez et al., 2014), and direct interpolation with the past could be risky. Ancient size data obtained from 
TABLE 4 I Lutjanus argentiventris total length to weight equation parameters from Mexico, Panama and Colombia (*data in $\mathrm{cm}$ were transformed into $\mathrm{mm}$ ).

\begin{tabular}{|c|c|c|c|}
\hline Reference & Country & $\mathbf{a}$ & b \\
\hline García-Contreras et al. (2009)* & Mexico & 0.0000126 & 3.03 \\
\hline Piñón et al. $(2009)^{*}$ & Mexico & 0.0000087 & 3.10 \\
\hline Bonilla-Gómez et al. (2014)* & Panama & 0.0000103 & 3.07 \\
\hline Rojas et al. (2004) & Colombia & 0.0000063 & 3.12 \\
\hline This study & Ecuador & 0.0000060 & 3.15 \\
\hline
\end{tabular}

A.

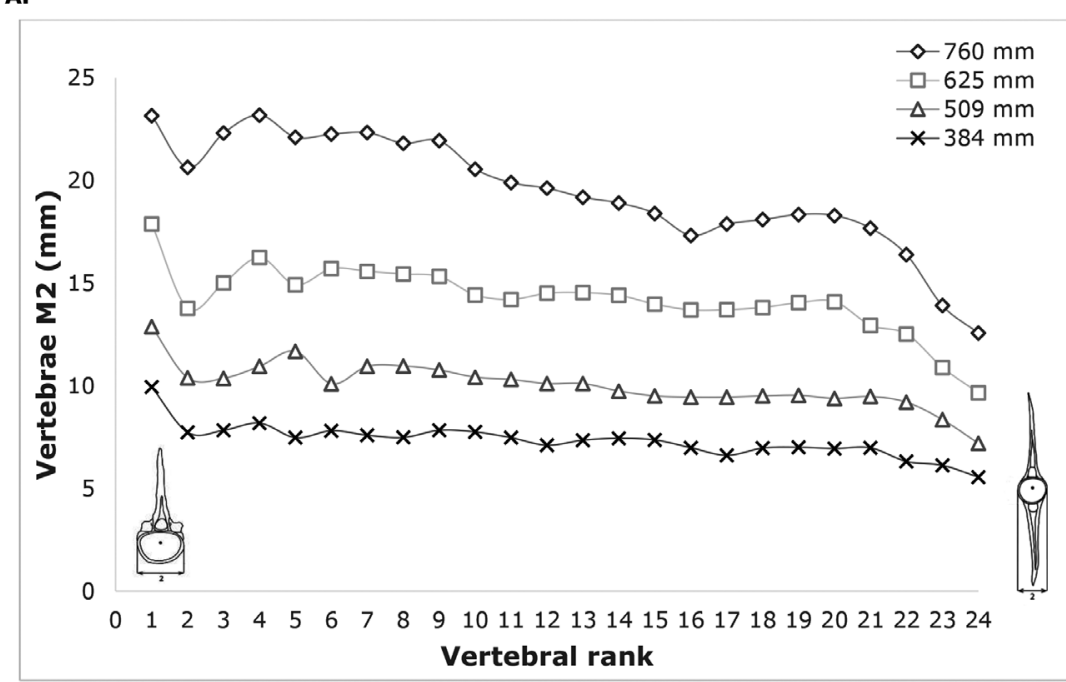

B.

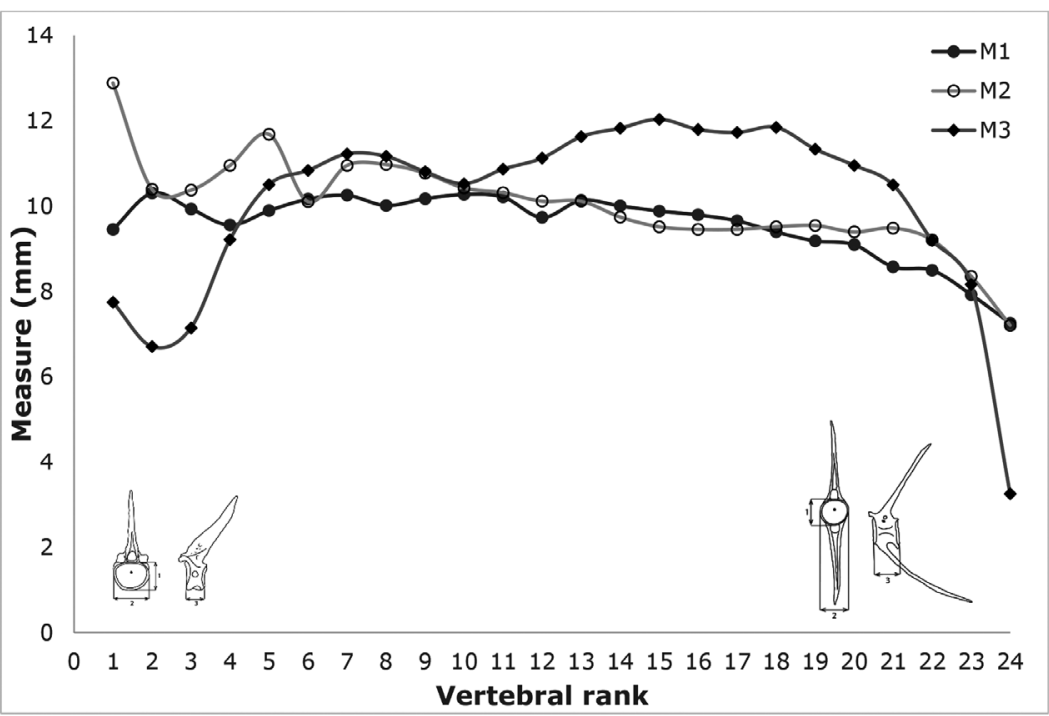

FIGURE 5 I Global Rachidian Profiles of Lutjanus argentiventris. A. Measurement 2 of four Lutjanus argentiventris individuals $(\mathrm{TL}=384 \mathrm{~mm} ; \mathrm{TL}=509 \mathrm{~mm} ; \mathrm{TL}=625 \mathrm{~mm} ; \mathrm{TL}=760 \mathrm{~mm})$. B. Measurements 1,2 and 3 of one Lutjanus argentiventris individual $(\mathrm{TL}=509 \mathrm{~mm})$. 
archaeological material could be helpful in modern ecological studies and fisheries management, given that such information could provide insight into: (1) the long-term effects of human activities on fisheries and aquatic ecosystems; (2) the acceleration and geographical extension of these effects over time; (3) the distribution and ecology of past fish populations (Erlandson, Rick, 2010).

The allometric model presented here can be used to predict the size and weight, not only of L. argentiventris, but also of its congeners, using isolated bones found in archaeological and paleontological contexts or the stomach contents of piscivorous species. This model could be useful not only for archaeologists but also for biologists working in historical ecology.

\section{ACKNOWLEDGMENTS}

The authors wish to thank Héctor Parrales, Cruz Elías Pincay, Enrique Toro, Johnny Vera and the numerous other fishermen who helped to obtain the fish. The Institut français d'études andines (IFEA) provided financial support to the second author. Thanks to Jill Cucchi for the copy-editing, to María del Pilar Martínez Polanco for preparing the map, and to the reviewers and to the editor for their valuable comments.

\section{REFERENCES}

- Aburto-Oropeza 0, DominguezGuerrero I, Cota-Nieto J, Plomozo-Lugo T. Recruitment and ontogenetic habitat shifts of the yellow snapper (Lutjanus argentiventris) in the Gulf of California. Mar Biol. 2009; 156(12):2461-72. https://doi. org/10.1007/s00227-009-1271-5

- Alava JJ, Lindop A, Jacquet J. Marine fisheries catch reconstructions for continental Ecuador: 1950-2010. Working Paper Series, Fisheries Centre, University of British Columbia, Vancouver. 2015:34.

- Allen GR. FAO Species Catalogue Vol. 6. Snappers of the world. An annotated and illustrated catalogue of lutjanid species known to date. FAO fish synop. 1985; 125(6).

- Allen GR. Lutjanidae. Pargos. In: Fischer W, Krupp F, Schneider W, Sommer C, Carpenter KE, Niem VH, editors. Guía FAO para la identificación de especies para los fines de la pesca Pacífico centro-oriental. Rome: FAO; 1995. p.1231-44.

- Barrett JH. An environmental (pre)history of European fishing: past and future archaeological contributions to sustainable fisheries. J Fish Biol. 2019; 94(6):1033-44. https://doi.org/10.1111/jfb.13929
- Béarez P. Comparaison des ichtyofaunes marines actuelle et holocène et reconstitution de l'activité halieutique dans les civilisations précolombiennes de la côte du Manabí Sud (Équateur). [PhD Thesis]. Paris: Muséum national d' histoire naturelle; 1996.

- Béarez P, Gay P, Lunniss R. Sea Fishing at Salango (Manabí Province, Ecuador) During the Middle Formative Machalilla Phase. Lat Am Antiq. 2012; 23(2):195-214. https://doi.org/10.7183/1045-6635.23.2.195

- Betts MW, Maschner HDG, Clark DS. Zooarchaeology of the "Fish that stops" using archaeofaunas to construct longterm time series of Atlantic and Pacific cod populations. In: Moss ML, Cannon A, editors. The archaeology of North Pacific fisheries. Fairbanks: University of Alaska Press; 2011. p.171-95.

- Betts MW, Noël S, Tourigny E, Burns M, Pope PE, Cumbaa SL. Zooarchaeology of the historic cod fishery in Newfoundland and Labrador, Canada. JONA. 2014; 24:121. 
- Bonilla-Gómez JL, Robles YA, Vega AJ. Length-weight relationship and biological information of the yellow snapper Lutjanus argentiventris from a tropical estuary: Río caté, Gulf of Montijo, Panama. J Appl Ichthyol. 2014; 30(1):227-29. https:// doi.org/10.1111/jai.12258

- Castellanos-Galindo G, Zapata-Padilla LA. Small-Scale fisheries on the Pacific coast of Colombia: historical context, current situation, and future challenges. In: Salas S, Barragán-Paladines MJ, Chuenpagdee R, editors. Viability and sustainability of small-scale fisheries in Latin America and The Caribbean. Gewerbestrasse: Springer International Publishing AG; 2019. p.79-100.

- Cooke RG, Ranere AJ. Precolumbian fishing on the Pacific Coast of Panama. In Blake M, editor. Pacific Latin America in Prehistory: the evolution of archaic and formative cultures. Pullman: Washington University Press; 1999. p.103-21.

- Cooke RG, Jiménez-Acosta M. Fishing at pre-Hispanic settlements on the Pearl Island archipelago (Panama, Pacific), I: Pedro González Island (4030-3630 cal BCE). In: Makowiecki D, HamiltonDyer S, Riddler I, Trzaska-Nartowski N, Makohonienko M, editors. Proceedings of the 15th meeting of the Fish Remains Working Group of the International Council for Archaeozoology. Poznan; 2009. p.167-71.

- Desse J. Propositions pour une réalisation collective d'un corpus: fiches d'identification et d'exploitation métrique du squelette des poissons. In: Desse-Berset $\mathrm{N}$, editor. 2èmes rencontres d'archéoichtyologie. Notes et Monographies Techniques. Valbonne: CRA-CNRS; 1984. p.67-86.

- Desse J, Desse-Berset N, Rocheteau M. Les profils rachidiens globaux. Reconstitution de la taille des poissons et appréciation du nombre minimal d'individus à partir des pièces rachidiennes. Rev paléobiol. 1989; 8(1):8994.

- Erisman B, Mascarenas I, Paredes G, Sadovy de Mitcheson Y, Aburto-Oropeza $\mathbf{O}$, Hastings P. Seasonal, annual, and long-term trends in commercial fisheries for aggregating reef fishes in the Gulf of California, Mexico. Fish Res. 2010; 106(3):279-88. https://doi.org/10.1016/j. fishres.2010.08.007
- Erlandson J, Rick T. Archaeology Meets Marine Ecology: The Antiquity of Maritime Cultures and Human Impacts on Marine Fisheries and Ecosystems. Annu Rev Mar Sci. 2010; 2:231-51. https://doi.org/10.1146/ annurev.marine.010908.163749

- Espino-Barr E, Cabral-Solís EG, GarcíaBoa A, Puente-Gómez M. Especies marinas con valor comercial de la costa de Jalisco, México. Manzanillo: CRIP; 2004.

- Espino-Barr E, Ruiz-Luna A, Arturo Garcia-Boa A. Changes in tropical fish assemblages associated with smallscale fisheries: a case study in the Pacific off central Mexico. Rev Fish Biol Fisher. 2002; 12:393-401. https://doi. org/10.1023/A:1025355102004

- Fricke R, Eschmeyer W, Van Der Laan R. Eschmeyer's Catalog of Fishes: Genera, Species, References [Internet]. 2020. Available from: http://researcharchive. calacademy.org/research/ichthyology/ catalog/fishcatmain.asp

- Froese R, Pauly D. FishBase. World Wide Web electronic publication. Available from: www.fishbase.org version (08/2019).

- Froyd CA, Willis KJ. Emerging issues in biodiversity \& conservation management: The need for a palaeoecological perspective. Quat Sci Rev. 2008; 27(1718):1723-32. https://doi.org/10.1016/j. quascirev.2008.06.006

- García-Contreras OE, QuiñónezVelázquez C, Morán-Angulo RE, ValdezPineda MC. Age, growth, and age structure of amarillo snapper off the Coast of Mazatlán, Sinaloa, Mexico. N Am J Fish Manag. 2009; 29(1):223-30. https://doi. org/10.1577/M06-025.1

- González-Acosta AF, De la Cruz Agüero G, De la Cruz Agüero J. Length-weight relationships of fish species caught in a mangrove swamp in the Gulf of California (Mexico). J Appl Ichthyol. 2004; 20(2):154-55. https://doi.org/10.1046/j.14390426.2003.00518.x

- Guzmán AF. Archaeoichthyological analysis of two Mexican Pacific sites. Quat Int. 2008; 185(1):34-45. https://doi. org/10.1016/j.quaint.2007.09.033

- Karachle P, Stergiou K. Morphometrics and Allometry in Fishes. In: Wahl C, editor. Morphometrics [Internet]. 2012. p.65-86. Available from: http://www.intechopen. com/books/morphometrics/morphometricsand-allometry-in-fishes 
- Lambrides ABJ, Weisler MI. Applications of vertebral morphometrics in Pacific Island archaeological fishing studies. Archaeol Ocean. 2015; 50(2):53-70. https:// doi.org/10.1002/arco.5059

- Lidour K, Vorenger J, Béarez P. Size and weight estimations of the spangled emperor (Teleostei: Lethrinidae: Lethrinus nebulosus) from bone measurements elucidate the fishing grounds exploited and ancient seasonality at Akab (United Arab Emirates). Int J Osteoarchaeol. 2018; 28(6):681-94. https://doi.org/10.1002/ oa. 2683

- Lucano-Ramírez G, Ruiz-Ramírez S, González-Sansón G, Ceballos-Vázquez BP. Reproductive biology of the yellow snapper, Lutjanus argentiventris (Pisces, Lutjanidae), from the Mexican central Pacific. Ciencias Mar. 2014; 40(1):33-44.

- Marean CW, Abe Y, Nilssen PJ, Stone EC. Estimating the minimum number of skeletal elements (MNE) in zooarchaeology: a review and a new image-analysis GIS approach. Am Antiq. 2001; 66(2):94-98. https://doi. org/10.2307/2694612

- Martínez-Polanco MF, JiménezAcosta M, Cooke RG. Fishing at preHispanic settlements on the Pearl Island Archipelago (Panama, Pacific), II: Bayoneta Island (900-1300CE). In: Makowiecki D, Hamilton-Dyer S, Riddler I, TrzaskaNartowski N, Makohonienko M, editors. Proceedings of the 15th meeting of the Fish Remains Working Group of the International Council for Archaeozoology. Poznan; 2009. p.172-78.

- Pauly D. Anecdotes and the shifting baseline syndrome of fisheries. Trends Ecol Evol. 1995; 10(10):430. https://doi. org/10.1016/S0169-5347(00)89171-5

- Peña-León GA. Pescadores de los raudales del río magdalena durante el periodo formativo tardío. CALDASIA. 2011; 33(2):295-314. Available from: https:// revistas.unal.edu.co/index.php/cal/article/ view/36391/38010

- Peña-León GA. Pescadores de los raudales del río Magdalena durante el período Formativo Tardío (Siglos V al I a.C.). Bogotá: Universidad Nacional de Colombia; 2013.
- Piñón A, Amezcua F, Duncan N. Reproductive cycle of female yellow snapper Lutjanus argentiventris (Pisces, Actinopterygii, Lutjanidae) in the SW Gulf of California: Gonadic stages, spawning seasonality and length at sexual maturity. J Appl Ichthyol. 2009; 25(1):18-25. https:// doi.org/10.1111/j.1439-0426.2008.01178.x

- Prestes-Carneiro G, Beárez P, Pearl Shock M, Prümers H, Jaimes Betancourt C. Pre-Hispanic fishing practices in interfluvial Amazonia: Zooarchaeological evidence from managed landscapes on the Llanos de Mojos savanna. PLoS ONE. 2019; 14(5): e0214638. https://doi.org/10.1371/ journal.pone.0214638

- Prestes-Carneiro G, Béarez P. Swamp-Eel (Synbranchus spp.) Fishing in Amazonia from Pre-Columbian to Present Times. J Ethnobiol. 2017; 37(3):380-97. https://doi. org/10.2993/0278-0771-37.3.380

- Reitz EJ, Quitmyer IR, Hale HS, Scudder SJ, Wing ES. Application of Allometry to Zooarchaeology. Am Antiq. 1987; 52(2):304-17. https://www.jstor.org/ stable/281782

- Rick TC, Lockwood R. Integrating paleobiology, archeology, and history to inform biological conservation. Conserv Biol. 2012; 27(1):45-54. https://doi. org/10.1111/j.1523-1739.2012.01920.x

- Robertson DR, Allen GR. Shorefishes of the Tropical Eastern Pacific: online information system [Internet]. Smithsonian Tropical Research Institute. 2015. Available from: https://biogeodb.stri. si.edu/sftep/es/pages

- Rojas PA, Gutiérrez CF, Puentes V, Villa AA, Rubio EA. Aspectos de la biología y dinámica poblacional del pargo coliamarillo Lutjanus argentiventris en el Parque Nacional Natural Gorgona, Colombia. Investig Mar. 2004; 32(2):2336. http://dx.doi.org/10.4067/S071771782004000200003

- Rojo-Vázquez J, Quiñonez-Velázquez C, Echavarria-Heras H, Lucano-Ramírez G, Godínez-Domínguez E, Ruiz-Ramírez S, Galván-Piña V, Sosa-Nishizaki O. The fish species composition and variation of catch from the small-scale gillnet fishery before, during and after the 1997-1998 ENSO event, central Mexican Pacific. Rev Biol Trop. 2008; 56(1):133-52. https://doi. org/10.15517/rbt.v56i1.5513 
- Rurua VA, Béarez P, Hermann A, Conte E. Length and weight reconstruction of Chlorurus microrhinos (Scaridae) from isolated cranial bones and vertebrae. Cybium. 2020; 44(1): 61-68. https://doi. org/10.26028/cybium/2020-441-008

- Sala E, Aburto-Oropeza O, Paredes G, Thompson G. Spawning aggregations and reproductive behavior of reef fishes in the Gulf of California. Bull Mar Sci. 2003; 72:103-21.

- Salas S, Chuenpagdee R, Charles A, Seijo JC. Coastal fisheries of Latin America and the Caribbean. Roma: FAO; 2011. 430p. Available from: http://www.fao.org/3/ai1926e.pdf

- Schwerdtner-Máñez K, Holm P, Blight L, Coll M, MacDiarmid A, Ojaveer H, Poulsen B, Tullet M. The Future of the oceans past: towards a global marincssse historical research initiative. PLOS ONE. 2014; 9(7): e101466. https://doi.org/10.1371/ journal.pone.0101466
- Thieren E, Van Neer W. New equations for the size reconstruction of sturgeon from isolated cranial and pectoral girdle bones. Int J Osteoarchaeol. 2016; 26(2):20310. https://doi.org/10.1002/oa.2407

- Teissier G. La relation d'allométrie. Sa signification statistique et biologique. Biometrics. 1948; 4(1):14-53.

- Velázquez-Velázquez E, Navarro Alberto J, Domínguez Cisneros SE, Vega Cendejas ME. Length-weight relationships for 24 fish species in a coastal lagoon of the Mexican South Pacific. J Appl Ichthyol. 2009; 25(2):228-29. https://doi.org/10.1111/ j.1439-0426.2008.01199.x

- Yeomans L. Size estimation of kingsoldier bream (Argyrops spinifer) and evidence of fishing strategies. Int J Osteoarchaeol. 2015; 26(5):799-807. https://doi.org/10.1002/ oa. 2481

\section{Neotropical Ichthyology}

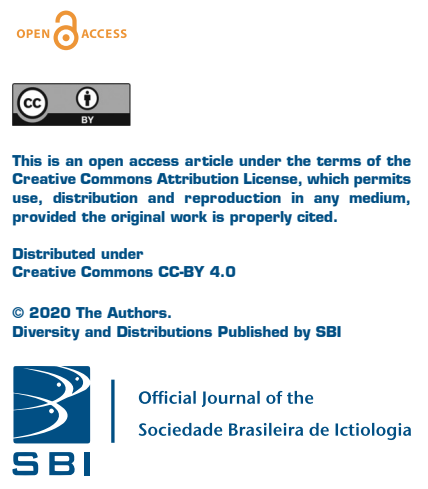

\section{AUTHOR CONTRIBUTION}

María Fernanda Martínez-Polanco: Conceptualization, Data curation, Formal analysis \& Writingoriginal draft.

Philippe Béarez: Conceptualization, Data curation, Formal analysis, Funding acquisition \& Writingoriginal draft.

\section{ETHICAL STATEMENT}

Not applicable.

\section{COMPETING INTERESTS}

The authors declare no competing interests.

\section{HOW TO CITE THIS ARTICLE}

- Martínez-Polanco MF, Béarez P. An osteometric approach to reconstruct the length and weight of Lutjanus argentiventris (Perciformes: Lutjanidae) for archaeological and ecological purposes. Neotrop Ichthyol. 2020; 18(3):e190106. https://doi.org/10.1590/1982-0224-2019-0106 